\title{
ORGANIZATIONAL AND ECONOMIC FUNDAMENTALS OF DEVELOPMENT OF SPORTS TOURISM IN THE SYSTEM OF MANAGEMENT OF SPORTS AND HEALTH ACTIVITIES
}

\author{
Olena Melikh', Inna Irtyshcheva ${ }^{2}$, Konstantin Bogatyrev ${ }^{3}$
}

\begin{abstract}
The article highlights the approaches to the development of sports and health activities and sports tourism in various spheres of society. It is proved that the current standard of quality of life in Ukraine is characterized as not satisfactory. Many factors affect the quality of life: lifestyle, genetic and environmental factors. However, one of the main issues remains the underfunding of development. The work investigates the state of financial support for health care, which is closely related to the level of low healthy life expectancy. It is determined that in modern conditions physical culture and sports are a necessary element of life of every Ukrainian. It is justified that grant programs are the main financial source for the development of physical culture and sports. It is proved that the state and non-state policy of development of physical education and sports should be built on creation of the corresponding concept for the next five years, which will include the appropriate strategy and program of development of physical culture and sports. The purpose of the article is a study of the peculiarities of organizing sports and health activities in different spheres of society and mechanisms of financing physical culture and sports in Ukraine. To achieve this goal, the following tasks are solved: to reveal the role and importance of organizing sports and health activities in different spheres of society; to conduct an analysis of the current state of financing of health care, physical education and sports; outline strategic guidelines for improving state and nongovernmental policies on financial provision for physical education and sports. Subject and object of study. The subject of the research is theoretical and practical aspects of organization of sports and health activities in different spheres of society. The object of the research is the process of managing sports and health activities in different spheres of society. Research methods. For a comprehensive study of the necessary information the basic methods of information research in management were used. In the study of the current state of financing the health care, physical education and sports the methods of statics and dynamics were used. The dynamic method was used to analyze health care expenditures in percentage terms to GDP and total expenditures, average life expectancy at birth in Ukraine, transition from one equilibrium state to another for the period from 1995 to 2017. The static method involved a comparison of the amount of annual funding from the State Targeted Social Program for the Development of Physical Culture and Sports and the actually allocated funds. An economic model of the dynamics of health care expenditures in percentage terms to GDP and total expenditures, average life expectancy at birth in Ukraine in the form of a graph is constructed.
\end{abstract}

Key words: sports tourism, health activity, physical culture, sports, management of sports and wellness activities.

JEL Classification: Z21, Z23

\section{Introduction}

Human health is a socially significant phenomenon, the level and condition of which can assess the wellbeing of society. The higher the level of the culture of health of the whole society, the higher the level of culture of healthy lifestyles of each person. The world experience shows that motion activity of a person throughout life prevents disease and improves health.

\footnotetext{
Corresponding author:

${ }^{1}$ Odessa National Academy of Food Technologies, Ukraine.

E-mail: melikh@gmail.com

${ }^{2}$ Admiral Makarov National University of Shipbuilding, Ukraine.

E-mail: innauamd@gmail.com

ORCID: https://orcid.org/0000-0002-7025-9857

${ }^{3}$ Admiral Makarov National University of Shipbuilding, Ukraine.

E-mail: bogatyrev@gmail.com
}

It is physical culture as a component of the general culture, the social manifestations of which is physical education and popular sport, is an essential factor in healthy lifestyles, prevention of diseases, organization of meaningful leisure and creation of conditions for comprehensive harmonious development of a person.

In recent years, Ukraine has begun to pay more attention to the development of recreation and health, 
i.e. sports tourism. Sports tourism is an integral part of the national system of physical culture and sports. It aims at promoting health, developing the physical, moral and volitional and intellectual abilities of a person by engaging in participation in sports trips of various complexity and competitions in the technique of sports tourism. Sports tourism performs a variety of sports, health, recreational, informative, educational, economic and other functions. However, due to a number of factors, the level of their realization does not correspond to the potential opportunities of the tourism and sports movement in Ukraine.

The main feature of sports tourism is that, unlike most other types of tourism and sports, it does not require relatively large material costs. Firstly, it develops in the existing natural environment and does not require significant investment for the preparation and holding of tourist and sports mass events and the installation of special facilities for their holding. Secondly, the logistical and organizational support of these measures is largely carried out by the forces and means of the tourists themselves. Thirdly, a public system of training and promotion of personnel has been established and is in operation, which can continue to function effectively with minimal expenditures by the state.

However, today, despite the potential for great opportunities, its social and economic importance, sports tourism in Ukraine is underdeveloped. The difficulties that sports tourism has encountered in its development are, first and foremost, related to the economic problems of social development, as well as to the almost complete lack of state and public support for this sport. That is, the development of sports tourism should be viewed through the prism of the system of management of sports and health activities.

\section{Management in the sports industry}

The current situation in the field of physical culture and sports in Ukraine is caused by the following factors: inconsistency of the legal framework in the field of physical culture and sports with modern requirements; inconsistency of the infrastructure of physical culture and health activity in the production, educational and social sphere to the needs of the citizens; imperfection of the system of centralized training of national teams, low level of financial and logistical support of children and youth and reserve sports; low level of scientific support for the development of physical culture and sports, underfunding for research; insufficient promotion of healthy lifestyles, children and youth and reserve sports; unsatisfactory condition of the material and technical base.

The level of providing the population in Ukraine with gyms (per 10 thousand people) is 2-3 times lower than in the leading states, for swimming pools it is 30 times lower. More than $80 \%$ of sports fields do not meet modern requirements; insufficient budget financing (from the state budget an average of $0.6 \%$ is allocated; $2 \%$ of their expenditures from the local budgets), inefficient attraction of extrabudgetary funds, a small amount of investments; the activities of launching and conducting state sports lotteries, which is one of the main sources of funding for sport in many European countries, are not carried out; imbalance in the system of education and advanced training of specialists, low wages, insufficient number of instructors in the field of fitness and health activity ( 1 employee of physical culture per 600 Ukrainians) (Horbenko, 2009).

The development of physical culture and sports is not only an indicator of social progress, but also one of the conditions for the growth of labor productivity, along with factors such as scientific and technological progress, advanced training and organization of work. Strategic management of the development of physical culture and sports is based on the use of a systematic approach, which is implemented through a systematic and situational analysis of the state of activity of organizations of physical and sports orientation.

As the field of physical culture and sport is positioned as an open socio-economic system, strategy development should be based on a deep analysis of external and internal factors that affect the performance of the sphere as a whole: the external factors are macroenvironment, the world experience of physical culture and sports; the microeconomic factors are the state of development of scientific research, the quality of methodological recommendations and developments, the characterization of personnel potential, the quantitative and qualitative aspects of material and technical support, the efficiency of use of financial instruments, the quality of preparation of sports reserves and institutional and management structure at all levels of management.

Increasingly relevant are the issues of improving the knowledge and skills of the members of management and retaining highly qualified personnel; discretionary actions of the state and further personification of the duties of civil servants; motivation of actions of senior officials in favor of the public interest. The practice of functioning of the system of physical training confirms the expediency of allocating the optimal number of general functions, which corresponds to the principle of sufficiency in terms of their practical use.

The main tasks of sports and health activity are: promotion and preservation of health; comprehensive development of physical abilities; deepening of the cultural knowledge necessary for using in everyday life; formation of conscious motivation for systematic physical education. The management of sports and recreational activities is becoming more significant in the global economic space every year, as the overall volume of the global sports industry market is constantly increasing. In addition, it is important to involve different groups of the population in health and recreational motor activity and 
the introduction of effective management, i.e. to create motivation, to select qualified specialists, to design an area of economic comfort. As a result, the demand for managers in the field of physical education and sports is increasing every year.

Therefore, there is an urgent need to train high-level specialists with modern management thinking, a system of specialized knowledge in the field of sports facilities management, who have fundamental and practical skills in managing sports and health activities and are able to apply them. In addition, scientific works in the field of sports and health activities are designed to identify talented, purposeful students and will help to develop and maintain the health of the younger generation. This will create a scientific basis for sports and wellness activities, increase prestige, contribute to reducing morbidity, improving the demographic situation, economic growth of Ukraine and the social climate.

\section{Features of financing of physical culture and sports in Ukraine}

Financing is a major factor in the sustainable development of any state. The welfare of the population depends on financial investments in any sphere of the national economy. Research of the current state of government funding in such areas as health care, physical education and sports is a major prerequisite for their further development. Identifying promising sources of funding for physical culture and sports will ensure their future development. An analysis of the current state of government support, through a targeted social program for the development of physical culture and sports for the period until 2020, will reveal the problems of financing and the imperfection of the respective system. All this creates the specifics of financial security and determines the prospects of the study.

According to Nikitenko S.V., the financing of physical culture and sports should be through the improvement of the national level, which requires:

- elaboration of a new strategy of the state policy of development of physical culture and sports in new socio-economic conditions;

- ensuring the implementation of the main provisions of the targeted program of development of physical culture and sports in Ukraine for the future;

- cross-sectoral coordination and functional regulation in the field of physical culture and sports;

- further development of the regulatory legal framework to support the fitness and sports movement, professional sports, including the participation of local units in the development of draft laws;

- creation of an adequate scientifically sound system of rehabilitation and physical education of the population; - development and implementation of cross-sectoral targeted programs on physical culture and sports development;
- training and retraining of highly qualified personnel; - methodical, financial, organizational support of preparation and performances of national teams at international competitions;

- creation of conditions for development of the sports industry in the country to attract investments in the field of physical culture and sports;

- carrying out all necessary works on mandatory certification of products and services in the field of physical culture and sports (Nikitenko, 2016).

Kononovych V.H. noted that there was a need for a clear definition and delineation of the strategic tasks of state and public organizations in the development of physical culture and sports. The low growth rates of extrabudgetary financial flows and their small share in the overall structure indicate the need for economic regulation of the bases for the creation of a favorable investment climate in the industry, both at the level of individual administrative units and the state as a whole (Kononovych, 2018).

Organizational basis for the development of physical culture and sports in Ukraine should be presented as an extensive network of sports clubs and centers of different ownership and orientation: health, for sports interests, from certain sports, etc. The state should take measures to create appropriate conditions for the functioning of such clubs and centers in educational institutions, enterprises, institutions and organizations, at the place of residence and mass recreation of the population. Economic activity in the field of physical culture and sports should be aimed at meeting the growing needs of the population of Ukraine in highquality fitness and sports services and contribute to the growth of business activity of subjects of all sectors of this sphere, harmonization of their economic relations with other entities (Zhurylo, 2017).

It is necessary to agree with the opinion of Lednov V.O., as he notes that "Modern sport is a dynamically developing industry, a new investment attractive sector of the economy. Business is increasingly cooperating with sports, many large companies are partners of the international and national federations for sports, professional leagues and clubs, as well as organizers of sports competitions. Sports for business is a very effective channel for promoting its products and services" (Lednov, 2010).

According to the Ukrainian Institute for Strategic Studies of the Ministry of Health of Ukraine, the current health condition of the Ukrainian population is estimated as unsatisfactory, which is related to:

- a high rate of overall mortality, which is steadily increasing. According to the European Health for All database, the higher than in Ukraine standardized mortality rates are recorded only in Russia, Kazakhstan and Moldova;

- low life expectancy levels (71.31 years, lower only in Russia, Kazakhstan, Turkmenistan); 
- low length of life ( 59.2 years);

- one of the highest natural depopulation in the European region.

The main prerequisites for a high mortality rate are risk factors such as smoking, excessive alcohol consumption, lack of exercise and excess weight. Doctors recommend treating sports and physical activity not as entertainment but as a compulsory element of every Ukrainian's life. If the situation does not change, in 2040 every second Ukrainian will complain of increased pressure and overweight. General global trends in increasing the incidence of residents are observed due to the passive lifestyle and the transfer of a significant percentage of business activity in the virtual space.

The negative factor of health care financing in Ukraine is a reduction in the consolidated budget expenditures to GDP from $4.8 \%$ in 1995 to $3.4 \%$ in 2017 , or 1.4 p.p. During the study period by 1 p.p. there was a reduction in health care expenditures in percentage terms of total expenditures. As the amount of health care expenditures decreases, the same is observed in the field of physical education and sports.

However, as it is noted above, physical education and sports are a major driving force in promotion and preservation of the human health, and therefore there is a need to analyze modern financial support and find alternative sources of funding. In Ukraine, the Concept of the State Targeted Social Program for the Development of Physical Culture and Sports for the Period to 2020 is adopted and currently operates. Its purpose is to give physical culture and sports in Ukraine a leading role as an important factor in a healthy lifestyle, disease prevention, the formation of humanistic values, the creation conditions for comprehensive harmonious development of the person, promotion of achievement of physical and spiritual perfection of the person, identification of reserve possibilities of an organism, formation of patriotic feelings in citizens and positive image of the state in the world community.

Kononovych V.H. notes that today there is no register of public organizations of physical and sports orientation in Ukraine. However, they can be divided into specific groups:

- national sports associations;

- fitness and sports associations;

- fitness and sports public organizations (federations, associations, unions, etc.) of a particular sport or group of sports;

- fitness and sports associations of social groups;

- sports clubs of different organizational and legal forms;

- teams of physical culture (Kononovych, 2018).

Most public and non-profit organizations can be involved today in the development of grant applications aimed at updating the material and technical resources of sports facilities, the development of educational and methodological recommendations for improving physical activity and healthy lifestyle.

Today, two projects have been developed in Ukraine: "The Strategy for the Development of Physical Education and Sports among the School-Age Youth until 2025" and "The Strategy for the Development of Physical Education and Sports among the Student Youth until 2025". The purpose of the two strategies is to create conditions for healthy physical activity and healthy lifestyles, to ensure the accessibility of sports for

PROJECT Strategy for the
Development of Physical
Education and Sports among the
Student Youth until 2025

PROJECT Strategy for the Development of Physical Education and Sports for SchoolAge Youth until 2025

State Targeted Social Program for the Development of Physical Culture and Sports for the Period up to 2020

Developed and implemented
The Concept of Development of Physical Education and Sports Among the Population of Ukraine until 2025

Strategy of Development of Physical Education and Sports Among the Population of Ukraine until 2025

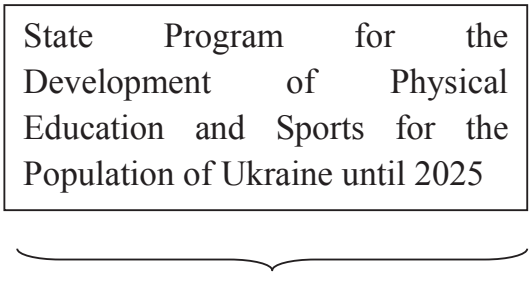

Proposition

Figure 1. Improvement of the state policy on the development of physical education and sports in Ukraine 
children, school-age youth, students to engage them in physical education and sports and to shape the health of citizens as the highest social value in the country. Having analyzed both strategies, we see similarities between them, so it is proposed to improve and create a general Concept of development of physical education and sports among the population of Ukraine until 2025. We consider it necessary to pay special attention to the development of the Concept of development of physical education and sports among the population of Ukraine until 2025 (Figure 1).

The Concept sets out the foundations of public policy to support the proper level of development of physical education and sport, namely: the totality of the goals of the development of physical education and sport, the system of national interests in this field and the priorities of state policy for ensuring the national security of the country. At the same time, the Strategy for the Development of Physical Education and Sports should specify and define a strategy for the implementation of the main provisions of the Concept of Development of Physical Education and Sports among the population of Ukraine until 2025 as the basis of the state policy towards ensuring the national security of the country and the proper financial provision for physical education, sports and health care. In general, the proposed measures to improve the state and non-state policies in the field of physical education and sports development will make it possible to increase the standard of living of the population.

\section{Conclusion}

Imptovement of the public health is one of the priorities of the present time. The state attaches particular importance to the substantiality of organization of sports and recreational activities in different spheres of society, according to the peculiarities of each of them. Today, Ukraine is lagging behind the standard of living of the European countries, ranking 150th among 223 countries in the world and 122nd among the UN members in terms of average length of life. The main factor leading to the deterioration of the development of the respective industry is the low funding. An analysis of the current state of health financing indicates a low level of security, from the so-called consolidated budget to GDP declined from $4.8 \%$ in 1995 to $3.4 \%$ in 2017 , or 1.4 p.p.

It is proved that in connection with the limitation of public financial resources the question regarding the search for alternatives arises. A promising source is grants, which are funds that are provided on a nonprofit basis to non-profit organizations or individuals for the implementation of social projects, charitable programs, research, training, and other socially useful purposes. It is justified that the current state policy on the development of physical culture and sports is imperfect. It is proposed to improve the state targeted social program and draft strategies for the development of physical culture and sports, by creating a new Concept for the Development of Physical Education and Sports among the Population of Ukraine until 2025, which will be a new strategy and program.

\section{References:}

Zhurylo, O. M. (2017). Derzhavne finansuvannia fizychnoi kultury ta sportu v Ukraini [State funding for physical culture and sports in Ukraine]. Ekonomichnyj visnyk Universytetu, 17/2, 261-264. (in Ukrainian)

Kononovych, V. H. (2018). Udoskonalennia derzhavnoho upravlinnia u sferi fizychnoi kultury i sportu pry oriientatsii na yevropeiskyi vektor rozvytku [Improvement of public administration in the field of physical culture and sport with a focus on the European vector of development]. Aktualni problemy derzhavnogo finansuvannya, 1(43), 426-431. (in Ukrainian)

Nikitenko, S. V. (2016). Osoblyvosti finansuvannia fizychnoi kultury ta sportu v Ukraini [Features of financing of physical culture and sports in Ukraine]. Derzhava ta regiony, 1(53), 103-106. (in Ukrainian)

Lednev, V. A. (2010). Industriya sporta kak arena konkurentnoy borbyi [Sports industry as an arena of competition]. «NAUKOVEDENYE». (in Russian)

Pro skhvalennia Kontseptsii Derzhavnoi tsilovoi sotsialnoi prohramy rozvytku fizychnoi kultury i sportu na period do 2020 roku vid 09.12.2015 № 1320-2015-r [On approval of the Concept of the State target social program for the development of physical culture and sports for the period up to 2020 dated 09.12.2015 № 1320-2015-p]. Retrived from: https://zakon2.rada.gov.ua/laws/show/1320-2015-\%D1\%80

Horbenko, O. V., \& Korniienko, I. H. (2009). Orhanizatsiino-upravlinski rezervy profesiino-oriientatsiinoi roboty VNZ haluzi fizychnoi kultury i sportu iz zahalnoosvitnimy shkolamy [Organizational and managerial reserves of vocational orientation work of HEIs in the field of physical culture and sports with secondary schools]. Mykolaiv: NUK. (in Ukrainian)

Tymoshenko, L. O., \& Labartkava, K. V. (2012). Sportyvnyi turyzm: navchalnyi posibnyk [Sport tourism: a textbook]. Lviv: LDUFK. (in Ukrainian)

Kysil, T., Kolodka, A., \& Rosokhata, A. (2014). Import Substitution as a Means of Image Forming: Prospects Forecast of Industrial Enterprises in Ukraine. Economics \& Sociology, 7(2), 123-135. 